\title{
Identifying Children's Language Learning Strategies: Turkish Example
}

\author{
ESIM GÜRSOY \\ Uludag University \\ ELIF EKEN \\ Bahçeşehir College
}

Received: 20 December 2016 / Accepted: 11 September 2017

ISSN: $1697-7467$

\begin{abstract}
Over the past two decades, there has been an upsurge of interest in language learning strategies (LLS). However, the research has so far mostly focused on older learners, primarily in ESL contexts and those of children in EFL contexts remained in its infancy. Thus the current study examines the English LLS use of 1116 Turkish $4^{\text {th }}$ and $5^{\text {th }}$ grade students by means of Children's Strategy Inventory for Language Learning (CHILLS). The results reveal that children's strategy preferences showed statistically significant differences with regard to gender, geographical region and academic achievement, the girls outperformed boys in strategy use and with regard to academic achievement $5^{\text {th }}$ grade students outperformed the $4^{\text {th }}$ grade students.
\end{abstract}

Keywords: Language learning strategies, children, CHILLS, successful language learners.

\section{Identificación de las estrategias de los niños para aprender un idioma: ejemplo turco}

RESUMEN: Durante las últimas dos décadas, ha resurgido el interés por las estrategias de aprendizaje de idiomas (LLS). Sin embargo, la investigación hasta ahora se ha centrado principalmente en los estudiantes más mayores, sobretodo en contextos de ESL, y en niños que tuvieron un contexto EFL en su infancia. De este modo, el estudio actual examina el uso del inglés LLS de 1116 estudiantes turcos de cuarto y quinto grado por medio del Inventario de las estrategias para el aprendizaje de idiomas para niños (CHILLS). Los resultados revelan que las preferencias de las estrategias de los niños mostraron diferencias significativas dependiendo del sexo, región geográfica y logros académicos. Las niñas superaron a los niños en el uso de la estrategia y, en cuanto a los logros académicos, los estudiantes de quinto grado superaron a los de cuarto.

Palabras clave: estrategias de aprendizaje, niños, CHILLS, estudiantes de idiomas con éxito.

\section{InTRODUCTION}

In recent decades, there has been a shift within the field of language learning and teaching with greater emphasis being put on learners and learning rather than on teachers and teaching. This shift in focus from teachers to learners has led researchers and scholars to carry out different studies on the characteristics of the learner and of the learning situation 
(Bialystok, 1981). Thus, the learners and their role in the learning process have become the primary concern in most research. In parallel to this new shift of interest, questions about how learners process new information have gained importance and prompt researchers to investigate language learning strategies (LLS) of L2 learners (Cohen, 1998; O' Maley \& Chamot, 1990; Oxford, 1990; Wenden \& Rubin, 1987). As Nyikos and Oxford (1993:11) state "learning begins with the learner"; therefore, "learning how to learn should be considered as the key competence which learners need to be equipped" (Strakova, 2013:38).

LLS have been investigated since the late 1970s and early 1980s (Gürsoy, 2010) and welcomed by the pioneering works of Rubin (1975), Stern (1975), Naiman, Fröhlich, Stern and Todesco (1978) providing valuable insight into characteristics, strategies and behaviors of 'good language learners'. They indicated that good language learners employed more and better learning strategies than poor language learners. It has been observed by a number of language educators that some learners who appear to be endued with particular cognitive and metacognitive behavior become more successful in the language learning process, whereas, some others fail to reach such success (Rubin, 1975).

All language learners, even children, use LLS consciously (Cohen, 1990; Oxford \& Cohen, 1992; Weinstein \& Mayer, 1986) or unconsciously (Ellis, 1986; Faerch \& Kasper, 1980, 1983; O’Malley \& Chamot, 1990; Wenden \& Rubin, 1987). Due to their different characteristics, children are different from adults with their limited cognitive abilities, world, conceptual and linguistic knowledge (Gürsoy, 2010). They benefit from early foreign language (FL) exposure using their natural language learning abilities and their openness to new experiences (Genesee, 2014).

Majority of the research on the LLS so far mostly focused on adolescents and adults (see Green \& Oxford, 1995; Griffiths \& Parr, 2001; Halbach, 2000; Kirsch, 2008; Sheorey, 1999). In particular, limited number of works has investigated the strategies of YLs. As stated by Purdie and Oliver (1999), the existence of social and psychological differences between adults and children prevented the spread of generalized results of LLS from adults to children. In addition, Hsiao and Oxford (2002) put emphasis on the differences in contexts where English was used as a second or FL, and Green and Oxford (1995) supported the idea that the use of strategies might vary depending on the learning environments. Therefore, with regard to the need to extend strategy research on YLs, in particular to EFL (English as a Foreign Language) contexts, this study contributes to the research field by exploring the learning strategies of YLs in an EFL context.

\section{Theoretical FrameWork OF Learning STRATEgies}

With the growing interest in student-centered learning, the concept of learning strategies, originated from the increased focus on cognitive psychology, has gained importance (Williams \& Burden, 1997). Oxford (1990:8) defined LLS as "specific actions taken by the learner to make learning easier, faster, more enjoyable, more self-directed, more effective and more transferable to new situations". Researchers (see O'Malley \& Chamot, 1990; Rubin, 1975, 1987) investigating the characteristics of the good language learner identified the strategies that these learners use during L2 learning (Gürsoy, 2010). However, although it was revealed 
by strategy research that all language learners could benefit from some type of strategies (Hong-Nam \& Leavell, 2007), the question that remains with us is whether the development of learning strategies in children differ from adults. As far as the differences between adult and child language acquisition is concerned, Purdie and Oliver (1999) argue that children approach language learning in the ways that are different from adults and adolescents both psychologically and socially. When the attention is directed to the question of to what extent child L2 learners differ from adult L2 learners, it becomes essential to investigate the LLS of children.

\subsection{Children as language learners}

Children naturally have some inborn advantages when it comes to learning languages, and their inborn ability leads to the general view that 'the younger is better' with regard to an ideal period of time to attain a language (Johnson \& Newport, 1989; Lenneberg, 1967). Lenneberg (1967) states that as the child grows older, s/he gradually loses his/her inborn flexibility to learn a language, and with the passing of time beyond the critical period, the level of success in proficiency automatically drops. As children approach puberty, they become more receptive of their self-image and identity (Brown, 1994) and as a result, the concept of affective filter becomes operative during this period, which has proved to be a great hindrance for success in language learning (Krashen, 1982). However, such an early start can be beneficial to learners in the long-run but it does not guarantee success in learning another language when we regard many other factors such as motivation, aptitude, learning styles, learning strategies etc. LLS among the many factors are "an extremely powerful learning tool" (O’Malley, Chamot, Stewner-Manzanares, Russo \& Küpper, 1985: 43) which help learners become successful by providing opportunities for learners to gain responsibility of their own learning (Alhaisoni, 2012). As emphasized by Littlewood (1996) learners need to keep on learning even outside the formal classroom setting. In this sense, it is important to identify the learner strategies at different age groups to help them perform better both inside and outside the classroom.

Relevant to this issue, understanding the differences of children from adults have importance (Gürsoy, 2010). Some differences are immediately obvious. Unlike adults, children are enthusiastic for learning and curious about the world. They like talking about themselves; however, they have quite short attention span and they can lose their attention easily (Harmer, 2012). Considering such differences, it is possible for them to use different strategies from those of adults. Therefore, it is potentially worth shedding light on the identification of strategies that children use.

\subsection{LLS Inventories}

With the growing research interest on LLS, numerous attempts have been made to classify strategies, however most of them considered adult language learners when making such categorizations (O’Malley \& Chamot, 1990; Oxford, 1990; Rubin, 1981). Among different classifications of LLS, Oxford's (1990) taxonomy was considered to be the most comprehensive one in accounting for the variety of strategies reported by language learners (Ellis, 1994). Oxford (1990) initially categorized LLS into two broad domains: Direct strategies and indirect strategies. In her taxonomy, direct strategies consist of memory strategies, 
cognitive strategies, compensation strategies. Indirect strategies include metacognitive strategies, affective strategies, and social strategies.

Based on this framework, Oxford (1990) developed SILL (Strategy Inventory for Language Learning) to report on the LLS use and it has been accepted and used extensively for research purposes around the world so far (Green \& Oxford, 1995; Griffths, 2003; Lan, 2005; Leung \& Hui, 2011; Maria \& Athena, 2015). Many research have been carried out regarding the effects of individual variables including age, gender, attitude, learning styles, motivation, proficiency, etc. on strategy use (Alharthi, 2015; Ehrman \& Oxford, 1990; Griffiths, 2003; Lee \& Oxford, 2008; Oxford \& Nyikos, 1989; Tabanlıoğlu, 2003; Wong \& Nunan, 2011; Xu, 2011)

Gender as one of the variables contributes to LLS. The studies investigating the effect of gender on LLS use have come to the conclusion that females are more frequent users of strategies (Ehrman \& Oxford, 1989; Hong-Nam \& Leavell, 2007; Oxford \& Ehrman, 1995; Zeynali, 2012). The factors contributing to gender differences in L2 strategy use have often a lot to do with differences in personality, cognitive style or hemispheric activation. Considering LLS use, female superiority is attributed to their greater social orientation and stronger verbal skills. Cognitively, females in comparison to males achieve more rapid verbal abilities in the first language development (Larsen-Freeman \& Long, 1991).

The earlier attempts on identifying LLS used by good language learners have led the researchers to investigate the relationship between LLS and success. The role of LLS was put on the assumption that independent language learners with greater control over their learning would become more successful than those who did not. It was found that there was a positive correlation between LLS use and student academic achievement (Sung, 2011; Vann \& Abraham, 1990). In the studies undertaken by Green and Oxford (1995), Griffiths (2003), Hong-Nam and Leavell (2007), Wu (2008), and Yang (2007) it was reported that high achievers used a range of LLS contrary to their underachieving counterparts who used LLS seldom.

As can be seen from the literature the majority of research concerned adults and adolescents and provided a wealth of information with regard to the relationship between LLS use and individual variables. Development of LLS in children has not been widely researched, because earlier taxonomies and inventories have been developed for older learners'. For this reason, there are a limited number of LLS studies with bilingual children, in immersion, ESL, or EFL contexts (see Chamot \& El-Dinary, 1999; Coyle \& Valcarcel, 2002; Doro \& Habok, 2013; Gunning \& Oxford, 2014; Lan \& Oxford, 2003; Maria \& Athena, 2015; Purdie \& Oliver, 1999; Wu, 2014). Given the scarcity of research with children, the results of earlier studies with older learners cannot be applied to children.

Since YLs learn and acquire language in the ways different from adults, it could be assumed that they may also use different strategies in accordance with their cognitive and psychological development. Regarding their unique characteristics, Gürsoy (2013) developed an inventory (Children's Inventory for Language Learning strategies, CHILLS) specific to children, in order to identify their LLS preferences. As different from SILL, CHILLS has four strategy groups and 30 items (strategies used specifically by EFL children). The first strategy group in CHILLS is for general study habits including mostly cognitive and metacognitive strategies, and two social strategies. The second category concerns strategies to improve language learning and composed of mostly cognitive, and metacognitive, social, 
compensation strategies. Third group has strategies used for the facilitation of the reception and production of the language and consists of mostly compensation strategies, two memory and two cognitive strategies. The last category is for the consolidation of the target language. Each statement was given in the form of a 3-point Likert scale ranging from "Yes", "Sometimes", to "No", considering YLs limited cognitive abilities to differentiate slight differences.

As with adults, children's language development is affected by the LLS. Thus they need to develop and use a range of strategies to manipulate the new input presented in language classrooms (Kirsch, 2012). In this sense, teachers as agents of changes in the learning environment are responsible to make learners aware of these strategies and to enable them to use a wider range of appropriate strategies (Oxford, 2003). In the learning process, LLS have particular importance at least for two reasons: First, they help learners use language more effectively (Oxford, 1990) and second, the use of these strategies enables learners to become more independent and autonomous learners (Allwright, 1990; Little, 1991 cited in Oxford, 2003). Coyle (2007) argues that strategic behavior is affected by the classroom culture, scaffolded learning and the creation of learning opportunities. Thus, in order to help students understand how to self-regulate their own learning, teachers need to identify the types of strategies they use, train them to use these strategies effectively, find out the ways relevant to children's abilities and skills. With this aim in mind, the current study is undertaken with YLs who are 10-11 years old and learning English as a Foreign Language (EFL) at state schools in Turkey to identify their LLS and the effects of variables such as achievement, gender, and geographical region on strategy use.

\section{3. Меthod}

The study aims to provide a comprehensive evidence for the research of LLS of YLs. In this sense, this study is significant in the research field by investigating YLs' LLS without any specific concentration on a specific strategy type or a language skill. A survey type research design is used in the study to answer the following research questions:

1. What is the overall LLS use of children in grades 4 and 5 ?

2. What is the most frequently used group of LLS?

3. What are the most and the least used strategies?

4. Is there any significant difference in use of LLS of the participants according to their gender, and geographical region?

5. Is there any significant difference in use of strategies between more successful learners and less successful learners?

\subsection{Participants}

The data is collected from a total of 1116 students who were $4^{\text {th }}$ and $5^{\text {th }}$ (age $10-11$ ) graders in Turkish state schools. Both schools and the classes were selected by using convenience sampling method initially and then, snow-ball sampling was implemented. 591 fourth grade, 525 fifth grade students from seven regions (Marmara: 181; Aegean: 104; 
The Mediterranean: 186; The Black Sea: 115; Central Anatolia: 151; East Anatolia: 344; Southeast Anatolia: 35) participated in this study.

\subsection{Instrument}

A quantitative approach was adopted to examine the types and frequency of use of LLS. The data was collected via CHILLS (Gürsoy, 2013) (see Appendix 1). The inventory was made up of two sections; Section one was about participants' demographic information such as grade level, gender, school and their grades on the school report cards. Section two consisted of 30 statements that were subdivided into 4 subscales (A, B, C, D): group A (A1-A10), general study habits; group B (B11-B18), improving language learning; group C (C19-C25), facilitating the reception and production of the language; and group D (D-26-D30) consolidation of the target language. Each statement was given in the form of a 3-point Likert scale ranging from "Yes", "Sometimes", to "No". Considering the fact that children at the ages of 10-11 are not fully developed cognitively and metacognitively the instrument does not use a five-point scale. The measurement was found highly reliable with a .86 alpha value.

\subsection{Data Collection and Analysis}

The inventory was administered to the students by their English language teachers and instructions were provided in Turkish before the administration. The data was analyzed by using SPSS 21. The participants' overall LLS use, the most frequently used group of LLS, and the most and the least frequently used strategy items were identified through descriptive statistics. Dual comparisons regarding the gender variable were made by T-test as the group variances were found homogenous. Regarding the geographical variable, comparisons were made by Kruskal Wallis test as the group variances were not homogenous. In order to compare LLS use of the more and less successful students T-test was used as the group variances were homogenous according to the Levene's test.

\section{RESULTS}

The first question of the study investigated the perceived strategy use of the participants. Since the instrument was a 3-point Likert scale, the total score ranged from 30 to 90 . The mean strategy score was calculated as 68,00 (SD 10,00), which indicates that the participants were moderate users of LLS.

Regarding the second question of the study, findings revealed that group A (strategies for general study habits) was reported to be used more than any other strategy group ( $\mathrm{M}=$ 23,04). The second and third most frequently used strategy groups were group B (strategies for improving language learning) $(\mathrm{M}=17,04)$ and group $\mathrm{C}$ (strategies to facilitate reception and production) $(\mathrm{M}=15,73)$ respectively. Strategies to consolidate the knowledge in the target language in group $\mathrm{D}$ were reported as the least frequently used strategy group among the participants $(\mathrm{M}=12,19)$.

The third question of the study investigated the most and the least used LLS items. The 
least frequently used strategy items reported were "I test myself to improve my English (M $=2,09$ ); to improve my English I work with supporting materials such as books, CDs that teach English $(\mathrm{M}=2,08)$ and I use the words I learnt recently when speaking with tourists and native speakers to pronounce them correctly $(M=1,66)$ ". As for the most frequently used strategy items: "I do tests to improve my English $(\mathrm{M}=2,61)$; Before I say something in English I check my book, notebook, etc. to see what we learnt about the topic $(\mathrm{M}=$ 2,54); I revise the lesson, the notes I take at school, my old book and notebooks, as well as unknown or newly learnt vocabulary by reading and writing $(\mathrm{M}=2,50)$."

Regarding the fourth research question of the study the results obtained from the T-Test analysis indicate that there are statistically significant differences between male and female learners in the overall strategy use $(\mathrm{t}=5.129, \mathrm{p}<.01)$ and in subscales $\mathrm{A}, \mathrm{B}, \mathrm{C}$, and D respectively by gender $(t=5.923,2.543,3.170,4.981, \mathrm{p}<.05)$ (Table 1). Female students reported using more strategies than male students.

Table 1. Gender differences in scores on CHILLS and its subscales

\begin{tabular}{|c|c|c|c|c|c|c|c|}
\hline \multicolumn{2}{|c|}{ Gender } & N & Mean & Std. Dev. & T & P & $\begin{array}{c}\text { Mean } \\
\text { Difference }\end{array}$ \\
\hline Overall & Female & 531 & 69,6836 & 10,07752 & 5,129 &, 000 & 3,07574 \\
Strategy & Male & 584 & 66,6079 & 9,93057 & 5,125 &, 000 & 3,07574 \\
A & Female & 531 & 23,7872 & 3,91489 & 5,923 &, 000 & 1,36254 \\
& Male & 584 & 22,4247 & 3,76330 & 5,912 &, 000 & 1,36254 \\
B & Female & 531 & 17,3089 & 3,17697 & 2,543 &, 011 &, 48865 \\
& Male & 584 & 16,8202 & 3,22887 & 2,545 &, 011 &, 48865 \\
C & Female & 531 & 16,0716 & 3,28957 & 3,170 &, 002 &, 59211 \\
& Male & 584 & 15,4795 & 2,94831 & 3,153 &, 002 &, 59211 \\
D & Female & 531 & 12,5160 & 2,01533 & 4,981 &, 000 &, 61206 \\
& Male & 583 & 11,9039 & 2,07779 & 4,988 &, 000 &, 61206 \\
\hline
\end{tabular}

As for the geographical region variable, since the results of the Levene test were not homogenous $(\mathrm{L}=8,19 ; \mathrm{p}<0,05)$, Kruskall Wallis was applied and significant difference was found among the use of the students from different regions (Asymp. sig< 0,05 ). In order to see the sources of such difference among seven regions, Mean Rank scores were interpreted. According to the results, while the students in Black Sea and Mediterranean regions were reported as the most frequent strategy users, the students in South East Anatolia region were reported as the least strategy users.

With regard to academic achievement, those with the score of 4 and 5 on their school report cards are identified as more successful, those with the score of 1,2 and 3 are considered 
less successful. T-Test was applied to identify the difference between the two groups and the variances were found as homogenous $(\mathrm{F}=0,698 ; \mathrm{p}>0,001)$. The sig. (2-tailed) value $<0,001$ shows that there is a significant difference in use of strategies between more successful $(\mathrm{M}=69.86, \mathrm{SD}=9.91)$ and less successful $(\mathrm{M}=65.51, \mathrm{SD}=9.53)$ students. It was reported that the difference was in favor of more successful students $[t(836)=5,802 \mathrm{p}<0,001]$.

\section{Discussion}

In this study, the LLS used by the fourth and fifth grade students in learning EFL were explored. For the entire group of students, it was found that the participants reported moderate use of LLS. The results indicate that there is room for developing YLs LLS in this EFL context in which strategy preferences seem to be dependent on. The fourth and fifth graders in Turkey receive three hours of compulsory English lessons a week. Although educational context appears to be an ideal space (Strakova, 2013) for the development of LLS repertoire, limited exposure to L2 is a preventative factor to increase students' awareness on strategy use. Strategy development also depends on the teachers' knowledge and skills. Therefore, the 'strategic' classroom having the potential to encourage independent learning has a crucial role in the development of LLS because it fosters the development of metacognitive knowledge (Dam 1995; Holec, 1981), which results in strategy development (Horwitz, 1987, 1988; Wenden, 1987, 1998, 2002).

With regard to specific strategy groups, "general study habits" (A) was reported as the most frequently used strategy group involving cognitive and metacognitive strategies. However, in this group items 8 and 1 with minimum mean scores indicate that they do not resort to someone else around them to speak, which maybe a result of their limited knowledge in expressing themselves in L2. SILL studies have shown that in many ESL contexts, students use LLS more than the students in EFL contexts (Green \& Oxford, 1995). Therefore, creating communicative environments with various learning opportunities may increase learners' need to use L2. "Consolidation of the target language" (D) was reported as the least frequently used strategy group. The strategies in this group require the ability to take responsibility of learning by increasing awareness about the process. The limited use of such strategies indicates a need for strategy training to contribute to learner autonomy.

When it comes to their least frequently used strategies, the reported items such as "I test myself to improve my English; To improve my English I work with supporting materials such as books, CDs that teach English" can be a reflection of exam-oriented education system in Turkey. It is important for children to learn when, how, and why to use these strategies, so that effective and intentional learning can take place (Brown, 1997). Another least frequently used strategy item "I use the words I learnt recently when speaking with tourists and native speakers to pronounce them correctly" indicates the limitation of EFL settings. Since students have limited or no contact with the native speakers, this strategy was reported to be the least frequently used one. As for the most frequently used strategy item "I do tests to improve my English" shows that language learning is regarded as a product in this educational setting, where grammar instruction heavily fills the course because of an exam-oriented education system. As it is stated by Çakan (2004), the students in Turkey 
are mainly exposed to multiple choice questions, which is a result of the examination and educational system. It is clearly seen that central examination system directs the children to use tests to develop their grammatical competence rather than the communicative one.

Another most frequently used item "Before I say something in English I check my book, notebook, etc. to see what we learnt about the topic; I revise the lesson, the notes I take at school, my old books and note books, as well as unknown or newly learnt vocabulary by reading and writing." The preference of such strategies is an indication of language instruction context that leads to the development of written language. The English Language Teaching Program (ELTP) (MoNE, 2017) emphasizes oral skills (listening and speaking) over written skills with YLs. Thus traditional methods are replaced with action-oriented and activity-based learning to help children develop interactional competence. The result may be interpreted in two ways: either the students' transfer their learning strategies gained from other courses to language classes or the teachers focus on accuracy and work on reading and writing skills more than the others. The finding is important in that it points out the importance of strategy training to develop YLs strategy repertoire and also that the language teachers in Turkey are not implementing the requirements of the ELTP (MoNE, 2017). With the global demand, the need for learning languages for communicative purposes has increased. Hence, to cope with this need, cooperation of the teachers is necessary to reach for the national and international goals.

Regarding the relationship of strategy use according to gender, the findings of the present study are consistent with the existing findings in the relevant literature with adults (Green \& Oxford, 1995; Hong-Nam \& Leavell, 2007; Oxford \& Ehrman, 1995; Zeynali, 2012; Zhou, 2010) and children and young adolescents (Doro \& Hobok, 2013; Lan, 2005; Maria \& Athena, 2015; Wu, 2014) in that the girls use LLS more than the boys. As stated in the previous literature (Larsen-Freeman \& Long, 1991), females' superiority can be related to the structure and operations of the brain. Likewise Oxford et al., (1988) explained gender differences by putting emphasis on females' greater overall social orientation; differences in males' and females' L2 speech; females' greater desire for social approval; females' greater willingness to accept existing norms, and females' greater general verbal ability.

Concerning the geographical region variable, the students' participating in this study from different regions of Turkey reported significantly different strategy preferences. The possible sources of such difference are not investigated in this study. Yet, identifying the correlation between socioeconomic status based on a combination of income, occupational prestige, education (Hess, Markson \& Stein, 1988) and LLS use might be necessary. Having different social backgrounds and socioeconomic statuses, students might have different resources to facilitate their language learning. Regarding the region variable, the difference between the strategy scores reported in the east and the other parts of the country can be explained by the local communities' ability to produce and consume the sources of society. Identification of YLs preference for certain strategies might help teachers to identify the cultural and contextual reasons behind students' use of those strategies (Chamot, 2004). Moreover, the relatively small number of respondents from the South East Anatolia region might also be the reason for limited use of LLS in that specific region which should be considered as the limitation of the study.

The examination of findings based on academic achievement revealed a positive correlation between LLS use and academic achievement. The current findings were consistent with 
the relevant literature (see Green \& Oxford, 1995; Griffiths, 2003; Hong-Nam \& Leavell, 2007; O'Malley et al., 1985; Wu, 2008; Yang, 2007). The current study shows that more successful students have employed the LLS far more frequently than less successful ones. There is no doubt that frequent use of LLS contributes to students' success. Therefore, strategy instruction is needed for the less successful students to help them become more successful learners. However, it should be remembered that although the learners somehow employ LLS, the difference shows itself in the frequency and variety which depend on a number of variables such as target language knowledge, gender, context, and learning style etc. (Chamot \& Kupper, 1989; Rubin, 1975).

\section{Conclusion}

With the spread of English across the globe, researchers in the field have started to search for better teaching methods, techniques and instructional materials serving for effective language learning. However, these efforts did not seem to live up to the expectations regarding the learners' progress in language due to individual differences such as gender, age, motivation, attitude, culture, etc. (Tabanlıoğlu, 2003). As "one size just does not fit all" (Oxford \& Leaver, 1996: 228), the field of language learning and teaching has seen a change with the greater emphasis being put on the language learner and learner variables rather than on teachers and teaching. Such shift has triggered an increase in the number of studies on learner characteristics.

LLS having a great influence on the rate and level of SLA (Ellis, 1994; Oxford, 1990) have been one of the subjects researchers have widely dealt with. However, most of the research participants in these studies were adults and adolescents. Thus the present study is significant because it investigates children's LLS in an EFL context by employing a children-specific inventory: CHILLS. Having the largest number of participants $(\mathrm{N}=1116)$, concerning the investigation of children's LLS in Turkey so far, this study provides insight about the children's strategy use and the need for strategy instruction for them to develop their strategy repertoire as well as to learn how to employ the LLS effectively.

The study has implications for teachers in EFL contexts as they are responsible for creating a supportive and effective environment in which children want to learn; facilitating comprehension in FL through linguistic and nonlinguistic support; encouraging children to use language in a productive way despite their limited FL knowledge. What does become apparent is the need for teachers to incorporate LLS into their teaching practices so that the intuitive use of these strategies as shown by the more effective learners could be extended to all children and become automatized at an early age (Coyle \& Valcarcel, 2002).

\section{REFERENCES}

Alhaisoni, E. (2012). "Language learning strategy use of Saudi EFL students in an intensive English learning context", in Asian Social Science, 8, 13:115-127.

Alharthi, T. (2015). "Learning styles and learning strategies in adult second language learning: A longitudinal case study", in Life Science Journal, 12, 2: 49-59. 
Bialystok, E. (1981). "The role of conscious strategies in second language proficiency", in Modem Language Journal, 65: 24-35.

Brown, H. D. (1994). Principles of Language Learning and Teaching. New Jersey: Prentice Hall.

Brown, A. L. (1997). "Transforming schools into communities of thinking and learning about serious matters", in American Psychologist, 52, 4: 399-413.

Chamot, A. U. and Kupper, L. (1989). "Learning strategies in foreign language instruction", in Foreign Language Annals, 22: 13-24.

Chamot, A. U. and El-Dinary, P. B. (1999). "Children's learning strategies in language immersion classrooms", in The Modern Language Journal, 83, 3: 319-338.

Chamot, A. U. (2004). "Singapore issues in language learning strategy research and teaching", in Electronic Journal of Foreign Language Teaching, 1, 1:14-26.

Cohen, A. D. (1990). Language Learning: Insights for Learners, Teachers and Researchers. New York: Newbury House.

Cohen, A. D. (1998). Strategies in Learning and Using a Foreign Language. London: Longman.

Coyle, Y. and Valcarcel, M. (2002). "Children's learning strategies in the primary FL classroom", in CAUCE, 25: 423-458.

Coyle, D. (2007). "Strategic classrooms: Learning communities which nurture the development of learner strategies", in Language Learning Journal, 35: 65-79.

Çakan, M. (2004). "Comparison of elementary and secondary school teachers in terms of their assessment practices and perceptions toward their qualification levels", in Ankara University Journal of Faculty of Educational Sciences, 37, 2: 99-114.

Dam, L. (1995). Learner Autonomy from Theory to Classroom Practice. Dublin: Authentik.

Doró, K. and Habók, A. (2013). "Language learning strategies in elementary school: The effect of age and gender in an EFL context", in Journal of Linguistics and Language Teaching, 4, 2: 24-37.

Ehrman, M. and Oxford, R. L. (1989). "Effects of sex differences, career choice, and psychological type on adult language learning strategies", in Modern Language Journal, 73,1: 1-13.

Ehrman, M. and Oxford, R. L. (1990). "Adult language learning styles and strategies in an intensive training setting", in Modern Language Journal, 74: 311-326.

Ehrman, M.; Leaver, B. and Oxford, R. (2003). "A brief overview of individual differences in second language learning", in System, 31, 3: 313-330.

Ellis, R. (1986). Understanding Second Language Acquisition. Oxford: Oxford University Press.

Ellis, R. (1994). The Study of Second Language Acquisition. Oxford: Oxford University Press.

Faerch, C. and Kasper, G. (1980). "Processes and strategies in foreign language learning and communication", in The Interlanguage Studies Bulletin, 5, 1: 47-118.

Faerch, C. and Kasper, G. (1983). Strategies in Interlanguage Communication. London: Longman.

Genesee, F. (2014): "Is early second language learning really better? Evidence from research on students in CLIL programs". Babylonia, 1, 14, available from: http://babylonia.ch/fileadmin/ user_upload/documents /2014-1/Genesee.pdf, accessed 11, May, 2015.

Green, J. M. and Oxford, R. L. (1995). "A closer look at learning strategies, L2 proficiency, and gender", in TESOL Quarterly, 29: 261-293.

Griffiths, C. and Parr, J. M. (2001). "Language-learning strategies: Theory and perception", in ELT Journal, 53: 247-54.

Griffiths, C. (2003). "Patterns of language learning strategy use", in System, 31: 367-383.

Gunning, P. and Oxford, R. L. (2014). "Children's learning strategy use and the effects of strategy instruction on success in learning ESL in Canada", in System, 43: 82-100.

Gürsoy, E. (2010). "Investigating language learning strategies of EFL children for the development of taxonomy", in English Language Teaching, 3, 3: 164-175. 
Gürsoy, E. (2013). "The development of a children's inventory for language learning strategies (CHILLS)", in Journal of Educational and Social Research, 3, 7: 263-272.

Halbach, A. (2000). "Finding out about students' learning strategies by looking at their diaries: A case study", in System, 28: 85-96.

Harmer, J. (2012). The Practice of English Language Teaching. Pearson, Cambridge: UK.

Hess, B. B., Markson, E. W. and Stein, P. J. (1988). Sociology: (3 $3^{\text {rd }}$ eds.). New York: Macmillan Publishing Company.

Holec, H. (1981). Autonomy and Foreign Language Learning. Oxford: Pergamon.

Hong-Nam, K. and Leavell, A. G. (2007). "A comparative study of language learning strategy use in an EFL context:

Monolingual Korean and bilingual Korean-Chinese university students", in Asia Pacific Education Review, 8,1:71-88.

Horwitz, E. K. (1987).”Surveying students' beliefs about language learning”, in A.L. Wenden and J. Rubin (eds.), Learner Strategies in Language Learning. Englewood Cliffs, NJ: Prentice Hall, 110-129.

Horwitz, E. K. (1988). "The beliefs about language learning of beginning university foreign language students", in Modern Language Journal, 72: 283-94.

Hsiao, T. Y. and Oxford, R. L. (2002). "Comparing theories of language learning strategies: A confirmatory factor analysis", in The Modern Language Journal, 86: 368-383.

Johnson, J. S. and Newport, E. L. (1989). "Critical period effects in second language learning: The influence of maturational state on the acquisition of English as a second language", in Cognitive Psychology, 21: 60-99.

Kirsch, C. (2008). Teaching Foreign Languages in the Primary School. NY: Continuum

Kirsch, C. (2012).'Developing children's language learner strategies at primary school", in Education 3-13, 40, 4: 379-399.

Krashen, S. (1982). Principles and Practice in Second Language Learning and Acquisition. Oxford: Pergamon.

Lan, R. and Oxford, R. L. (2003). "Language learning strategy profiles of elementary school students in Taiwan", in IRAL, 41: 339- 379 .

Lan, R. L. (2005). Language learning strategies profiles of EFL elementary school students in Taiwan. Unpublished Doctoral Dissertation. University of Maryland, College Park, MD. USA

Larsen-Freeman, D. and Long, M. (1991). An Introduction to Second Language Acquisition Research. Oxford: Oxford University Press.

Lee, R. K. and Oxford, R. (2008). "Understanding EFL learners' strategy use and strategy awareness", in Asian EFL Journal, 10, 1: 7-32.

Lenneberg, E. H. (1967). Biological Foundations of Language. New York: Wiley.

Leung, Y. and Hui, A. N. (2011). "Language learning strategy of Hong Kong Putonghua learners", in Educational Research Journal, 26, 1: 17-39.

Littlewood, W. (1996). "Autonomy: An anatomy and a framework", in System, 24, 4: 427-435.

Maria, P. and Athena, S. (2015). "Exploring relationships with grade level, gender and language proficiency in the foreign language learning strategy use of children and early adolescents", in International Journal of Research Studies in Language Learning, 4, 1: 83-96.

Ministry of National Education (MoNE). (2017). English language teaching program (Primary and Secondary School Grades 2, 3, 4, 5, 6, 7 and 8). [Milli Ĕgitim Bakanlı̆̆ izce dersi ögretim programı (ilkokul ve ortaokul 2, 3, 4, 5, 6, 7 ve 8. Sinıflar).] Ankara.

Naiman, N.; Frochlich, M.; Stern, H. H. and Todesco, A. (1978). The Good Language Learner. Toronto: Ontario Institute for Studies in Education. 
Nyikos, M. and Oxford, R. L. (1993). "A factor analytic study of language learning strategy use: Interpretations from information-processing theory and social psychology", in Modern Language Journal, 7: 11-22.

O’Malley, J. M.; Chamot, A. U.; Stewner-Manzanares, G.; Rocco, R. and Küpper, L. (1985). "Learning strategy applications with students of English as a second language", in TESOL Quarterly, 19: 557-584.

O’Malley, J. M. and Chamot, A. U. (1990). Learning Strategies in Second Language Acquisition. UK: Cambridge University Press.

Oxford, R. L.; Nyikos, M. and Ehrman, M. (1988). "Vive la difference? Reflections on sex differences in use of language learning strategies", in Foreign Language Annals, 21, 4: 321-329.

Oxford, R. L. and Nyikos, M. (1989). "Variables affecting choice of language learning strategies by university students", in The Modern Language Journal, 73, 3: 291-300.

Oxford, R. L. (1990). Language Learning Strategies: What Every Teacher Should Know? USA: Heinle and Heinle Publishers.

Oxford, R. and Cohen, A. (1992). "Language learning strategies: Crucial issues of concept and classification", in Applied Language Learning, 3, 1-2: 1-35.

Oxford, R. L. and Ehrman, M. E. (1995). “Adults' language learning strategies in an intensive foreign language program in the United States", in System, 23: 359-386.

Oxford, R. L. and Leaver, B. L. (1996). "A synthesis of strategy instruction for language learners", in Rebecca L. Oxford (ed.). Language Learning Strategies around the World: Cross-cultural Perspectives. (Technical Report). Honolulu: University of Hawaii, Second Language Teaching \& Curriculum Centre, 227-246.

Oxford, R. (2003). "Language learning styles and strategies: An overview". Proceedings of GALA (Generative Approaches to language acquisition). Conference, 1-25, available from: http:// web.ntpu.edu.tw/ language/workshop/read2.pdf, accessed 10, March, 2015.

Purdie, N. and Oliver, R. (1999). "Language learning strategies used by bilingual school-aged children", in System, 27: 375-388.

Rubin, J. (1975). "What the good language learner can teach us", in TESOL Quarterly, 9: 41-51.

Rubin, J. (1981). "Study of cognitive processes in second language learning", in Applied Linguistics, 2: 117-131.

Rubin, J. (1987). "Learner strategies: Theoretical assumptions, research history and typology", in A. L. Wenden, and J.

Rubin (eds.), Learner Strategies in Language Learning. UK: Prentice Hall International Ltd., 15-30.

Sheorey, R. (1999). "An examination of language learning strategy use in the setting of an indigenized variety of English", in System, 27:173-190.

Stern, H. H. (1975). "What can we learn from the good language learner?", in Canadian Modern Language Review, 34: 304-318.

Strakova, Z. (2013). "Developing cognitive strategies in foreign language education", in Journal of Language and Cultural Education, 1, 1: 37-50.

Sung, K. (2011). "Chinese as a foreign language learners' strategy use and writing achievement", in New Waves-Educational Research and Development, 14, 1: 67-84.

Tabanlığlu, S. (2003). The Relationship between learning styles and language learning strategies of pre-intermediate EAP students. Unpublished Master Thesis. METU Social Sciences Institute.

Vann, R. J. and Abraham, R. G. (1990). "Strategies of unsuccessful language learners", in TESOL Quarterly, 24, 2: 177-198.

Weinstein, C. E. and Mayer, R. E. (1986). "The teaching of learning strategies", in Wittrock, M. C. (eds.). Handbook of Research on Teaching. New York: MacMillan. 
Wenden, A. (1987). "How to be a successful language learner: Insights and prescriptions from L2 learners", in J. Rubin and A. L. Wenden (eds.), Learner Strategies in Language Learning. Englewood Cliffs, N. J.: Prentice Hall, 103-18.

Wenden, A. (1998). "Metacognitive knowledge and language learning", in Applied Linguistics, 19: $515-37$.

Wenden, A. (2002). "Learner development in language learning", in Applied Linguistics, 23: 32-55.

Wenden, A. and Rubin, J. (1987). Learner Strategies in Language Learning. Englewood Cliffs, N. J., Prentice Hall.

Williams, M. and Burden, R. (1997). Psychology for Language Teachers: A Social Constructivist Approach. Cambridge: Cambridge University Press.

Wong, L. L. C. and Nunan, D. (2011). "The learning styles and strategies of effective language learners", in System, 39:144-163.

$\mathrm{Wu}, \mathrm{Y}$. (2008). "Language learning strategies used by students at different proficiency levels", in Asian EFL Journal, 10, 4: Conference Proceedings.

Wu, Y. (2014). "Characteristics of Chinese primary school students' EFL learning strategies", in Theory and Practice in Language Studies, 4, 6: 1266-1272.

$\mathrm{Xu}, \mathrm{X}$. (2011). "The relationship between language learning motivation and the choice of language learning strategies among Chinese graduates", in International Journal of English Linguistics, 1, 2: 203-212.

Yang, M. (2007). "Language learning strategies for junior college students in Taiwan: Investigating ethnicity and proficiency", in The Asian EFL Journal, 9, 2: 35-57.

Zeynali, S. (2012). "Exploring the gender effect on EFL learners' learning strategies", in Theory and Practice in Language Studies, 2, 8: 1614-1620.

Zhou, Y. (2010). "English language learning strategy use by Chinese senior high school students", in English Language Teaching, 3, 4: 152-158. 